\title{
INTERSPINOUS SPACER IN PERSISTENT DISCOGENIC PAIN: PERCUTANEOUS APPROACH OR OPEN TECHNIQUE
}

\author{
ESPAÇADOR INTERESPINHOSO EM DOR DISCOGÊNICA PERSISTENTE: \\ ACESSO PERCUTÂNEO OU TÉCNICA A CÉU ABERTO \\ ESPACIADOR INTERESPINOSO EN DOLOR DISCOGÉNICO PERSISTENTE: \\ VÍA PERCUTÁNEA O TÉCNICA ABIERTA
}

José Antonio Cruz Ricardez', Jesús Alfonso Cao Romero Arroyo ${ }^{1}$

1. Hospital Universitario de Puebla.

\begin{abstract}
Objective: To compare the postoperative clinical course of placement of interspinous spacer with open technique (ISO) with percutaneous interspinous spacer (PIS). Methods: Quasi-experimental, longitudinal study of 42 patients with discogenic pain uncontrolled with analgesics, aged 35-55 years old, 21 women, and 21 men. Clinical history, location of pain, VAS scale before and after surgery, Oswestry Disability Index and Macnab modified scale at 6 months were used. Results: When performing quantitative analysis statistical significance $(p=0.0478,0.0466,0.0399)$ was demonstrated with Student's $t$ test between the results according to VAS scale; in the qualitative analysis with the Oswestry index and Macnab modified scale it was demonstrated the hypothesis that the results is dependent of the surgical technique. Conclusions: According to the results, we can conclude that there is a statistically significant difference depending on the surgical technique used with respect to the rate of disability and functionality in daily life as well as in the improvement of pain symptoms.
\end{abstract}

Keywords: Low back pain; Spondylolisthesis; Diskectomy; Diskectomy percutaneous.

\section{RESUMO}

Objetivo: Comparar a evolução clínica pós-operatória da colocação de espaçador interespinhoso com técnica a céu aberto (ElA) com a colocação percutânea do espaçador interespinhoso percutâneo (EIP). Métodos. Estudo quase experimental, longitudinal de 42 pacientes com dor discogênica não controlada com analgésicos, na faixa etária de 35 a 55 anos de idade, 21 mulheres e 21 homens. Empregou-se história clínica, localização da dor, escala EVA antes e após a cirurgia, índice de incapacidade de Oswestry e escala modificada de Macnab aos 6 meses. Resultados. Ao se realizar a análise quantitativa, verificou-se significância estatística $(p=0,0478,0,0466,0,0399)$ com o teste t de Student entre os resultados, de acordo com a escala EVA; na análise qualitativa, com a escala de Oswestry e de Macnab modificada foi demonstrada a hipótese de que o resultado é dependente da técnica cirúrgica. Conclusões: De acordo com os resultados obtidos, podemos concluir que há uma diferença estatisticamente significante, dependendo da técnica utilizada com relação à taxa de incapacidade e funcionalidade na vida diária, assim como na melhora dos sintomas dolorosos.

Descritores: Dor lombar; Espondilolistese; Discotomia; Discotomia percutânea.

\section{RESUMEN}

Objetivo: Comparar la evolución clínica posquirúrgica de la colocación de espaciador interespinoso abierto (ElA) contra la colocación de espaciador interespinoso percutáneo (EIP). Método: Estudio cuasi-experimental, longitudinal de 42 pacientes con dolor discogénico no controlado con analgésicos, con un rango de edad de 35 a 55 años, 21 mujeres y 21 hombres. Se utilizó historia clínica, localización del dolor, escala EVA pre y posquirúrgica, test de discapacidad de Oswestry y la escala modificada de Macnab a los 6 meses. Resultados: Al realizar el análisis cuantitativo se demostró una significación estadística ( $p=0,0478,0,0466,0,0399)$ con la prueba t de Student entre los resultados de acuerdo a la escala de EVA; en el análisis cuantitativo con la escala modificada de Macnab y Oswestry se demostró la hipótesis en la que el resultado es dependiente de la técnica quirúrgica empleada. Conclusiones: De acuerdo a los resultados obtenidos podemos concluir que hay diferencia estadística dependiendo de la técnica quirúrgica utilizada con respecto al índice de discapacidad y funcionalidad en la vida diaria, así como en la mejoría de la sintomatología álgica.

Descriptores: Dolor de la región lumbar; Espondilolistesis; Discectomía; Discectomía percutánea.

\section{INTRODUCTION}

Chronic pain affects one quarter of the general population, averaging around $27 \%$. Approximately one quarter of patients with chronic pain, have low back pain. This condition causes physical limitations that change the social and emotional environment of the patient. ${ }^{1}$
Lumbalgia results in costs associated with work disability and the treatment used. In this regard, approximately $30 \%$ of those suffering from low back pain in Mexico retire due to disability. ${ }^{1}$ Discogenic pain has been defined as pain originating from the intervertebral disc itself. It is not radicular and can occur in the absence of spinal deformities, instability, or signs of neural tension. Although 
the outer edge of the disc can remain intact, multiple processes can stimulate the multiplication and possible sensitization of the pain nociceptors in the disc, independently of nerve root symptoms. ${ }^{2}$ The concept of discogenic pain was introduced by Inman and Saunders in 1947 and the term was used for the first time by Fernstrom in 1969 cited by R. C. Miralles and M. Rull to establish an association between annular stimulation and the p erception of shoulder pain identified during in vivo studies. ${ }^{2}$

The outside third of the fibrous ring is richly innervated and these nerves can extend as deep as the middle third of the annulus. This innervation comprises the anatomical foundation for discogenic pain

It is a classic pattern primarily located in the central lumbar region, which can be referred to as the gluteal region, without true radiculopathy, and with chronic, intermittent, or even disabling evolution in some cases. It mainly affects young adults between thirty and fifty years of age. ${ }^{3}$

During the evolution of the different types of treatment for diseases of the spine, we can observe advances in the surgical procedures that achieve dynamic or flexible stability, enabling a certain mobility of the vertebral segment. ${ }^{3}$

The interspinous spacer is a device inserted between the spinous process apophyses of the affected spinal segment with the objective of limiting extension and thus alleviating the compressive symptomology and at the same time enabling flexion, axial rotation, and lateral inclination at this level. ${ }^{4}$

Dynamic stabilization is defined as a system that favorably modifies mobility and load transmission of a spinal segment, without performing fusion of that segment. In other words, the stabilizer only restricts the movement of the affected segment in the direction or plane that causes the pain. ${ }^{4,5}$

Interspinous decompression is a minimally invasive surgery with indications for use as an adjuvant alternative together with other surgical or non-surgical treatment that can help the pain symptoms without creating significant patient risk. ${ }^{6}$

Conservative, non-surgical treatments have failed to resolve pain symptoms. ${ }^{6}$

Discectomies lead to discal recurrences. ${ }^{6}$

Disc degeneration at the level adjacent to a prior fusion. ${ }^{7}$

Cauda equina syndrome. ${ }^{6}$

Grade 1 spondylolisthesis. ${ }^{6}$

Elderly patients with significant medical histories who cannot tolerate invasive sugery. ${ }^{6}$

For the open technique, a traditional incision is made in the midline, considering the spinous process apophyses of the affected segments with an incision of approximately $10 \mathrm{~cm}$. (Figure 1)

For the percutaneous procedure, the use of transurgical imaging support is essential to be able to locate the exact levels and the level of the interspinous space. The spacer is placed in the affected segment with a lateral incision of $2 \mathrm{~cm}$. (Figure 2)

\section{OBJECTIVE}

To compare the postoperative clinical evolution of the open placement of the interspinous spacer (OIS) to that of the percutaneous placement of the interspinous spacer (PIS).
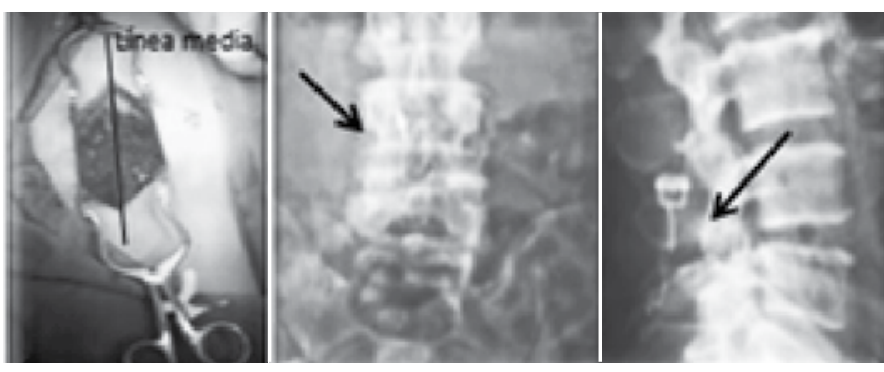

Figura 1. A) Open technique wound. B) Anteroposterior radiograph of the lumbar spine with Biolig spacer. (C) Lateral radiograph of the lumbar spine with Biolig spacer.

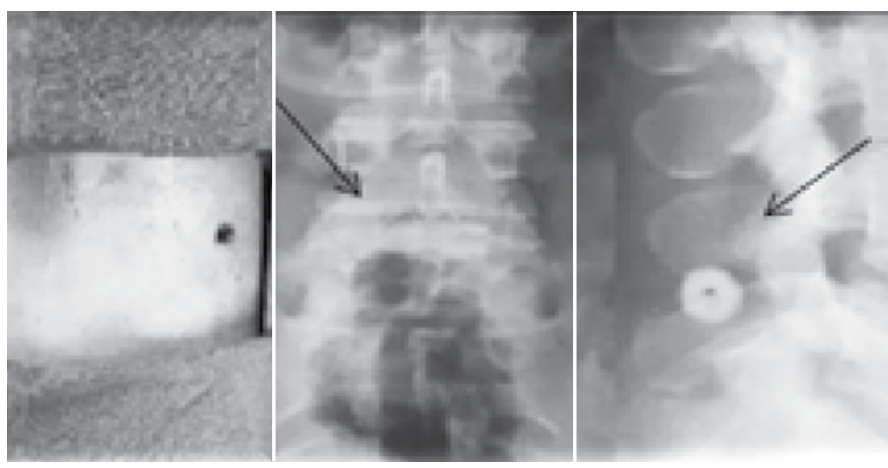

Figura 2. A) Percutaneous technique wound. B) Anteroposterior radiograph of the lumbar spine with Liv-Space spacer. C) Lateral radiograph of the lumbar spine with 01 Liv-Space spacer.

\section{MATERIAL AND METHODS}

A quasi-experimental, non-randomized, longitudinal study of 42 patients with discogenic pain who underwent previous conservative treatment at the outpatient clinic of the spine module at the Hospital Universitario de Puebla during the period between January 2014 and February 2015. Various questionnaires were used to satisfy the specifications for inclusion and exclusion criteria. (Tables 1 and 2) The detailed medical history, predominant location of pain, and a detailed physical examination were used to determine the type of pain studied.

Each patient answered a questionnaire using the visual analog scale (VAS) that corresponded to the most significant intermittent episode experienced and this same method was used in postoperative followup at one week, one month, and six months in order to be able to compare the evolution of pain for each of the techniques performed. A section was developed to show the outcomes of the surgical techniques used in terms of functionality in the daily life of the patient and recovery of their normal activities after six months using the Oswestry Disability Index and the Modified Macnab scale.

The study was approved by the Ethics Committee under approval number 15546 (03/2016) and the patients signed an informed consent form.

Table 1. Exclusion criteria.

Radicular Pain

Magnetic Resonance with discal protrusion

Spondylolisthesis

Prior spine surgery

Table 2. Inclusion criteria.

Either sex

Age from 35 to 55 years

Signed informed consent form

Pain episodes with VAS $>8$

Typical discogenic pain

VAS $>5$ even with NSAIDs

Prior strengthening of lower back in the rehabilitation service

Went to the outpatient clinic of the spine module of the Hospital Universitario de Puebla.

Discogenic pain for a minimum of 6 months

\section{RESULTS}

In this study of 42 patients, 27 were treated via the open technique and 15 via the percutaneous technique. The predominant age group at $60 \%$ was between 45 and 55 years of age, with the remaining $40 \%$ between 
the ages of 35 and 45 . Fifty per cent were male and $50 \%$ were female. The disease was present at one level in $66.6 \%$ and at two levels in $33.4 \%$ of the patients, with the most commonly affected level being L4-L5 at 70\%, followed by L5-S1 at 23\% and L3-L4 at 6.9\%.

In conducting a quantitative analysis of the results obtained using the VAS scale, we found a preoperative average of 8.6 points during the intense pain episode. Taking this score into account, we compared it against the same scale during the postoperative phase of the two techniques used. During the first week, we recorded a decrease of $4.6 \pm 2.1$ for the OIS and of $5.1 \pm 1.6$ for the PIS, with an average difference of 0.5 points between the procedures. An evaluation of the patients one month following the surgical procedure showed improvement for both procedures, with a difference of 1.3 points (OIS: 2.7 , PIS: 1.4). The final evaluation conducted at 6 months had significant clinical results for both techniques with an average 1.1 point difference between them (OIS: 2.2, PIS: 1.1). The Student's $t$ test was performed to check the statistical difference between the two techniques giving us a result of $p<0.5$ in all cases. (Table 3 )

The contingency table and the chi-squared test were used to perform qualitative analysis of the Modified Macnab scale and Oswestry Disability Index variables at 6 months following surgery, with the main question being whether or not the outcome from the placement of interspinous spacers in patients with persistent discogenic pain is dependent on the surgical technique used, with the following results: $X^{1}: 0.0172>X^{\circ}$ : 0.0025 , supporting the assumption that scores resulting from the Macnab Modified Scale and the Oswestry Disability Index are dependent on the technique used. (Tables 4 and 5)

Table 3. Oswestry of the patients (as percentages) $\mathrm{N}=110$.

\begin{tabular}{c|c|c|c|c}
\hline Time of evaluation & Average & Minimum & Maximum & SD \\
\hline Preoperative & 36.8 & 28 & 40 & 4.02 \\
\hline 30 days & 8.80 & 0 & 34 & 12.08 \\
\hline 180 days & 10.40 & 0 & 40 & 16.02 \\
\hline 365 days & 10.6 & 0 & 40 & 15.89 \\
\hline
\end{tabular}

Table 4. Modified Macnab scale at 6 months.

\begin{tabular}{c|c|c|c}
\hline Technique used & Poor & Fair & Good \\
\hline OIS & $3.70 \%$ & $11.10 \%$ & $85.20 \%$ \\
\hline PIS & $0 \%$ & $13.20 \%$ & $86.80 \%$ \\
\hline
\end{tabular}

Table 5. Oswestry Disability Index at 6 months

\begin{tabular}{c|c|c|c}
\hline Technique used & Severe & Moderate & Minimal \\
\hline OIS & $4.40 \%$ & $15.40 \%$ & $80.20 \%$ \\
\hline PIS & $0 \%$ & $14.90 \%$ & $85.10 \%$ \\
\hline
\end{tabular}

\section{DISCUSSION}

The interspinous spacers were introduced to the market as an alternative for decompression of the spinal canal in diseases like lumbar spinal stenosis. Later, they were used for lumbalgia from discogenic pain and the newest trend is to use them for vertebral fusion. It has been compared to decompression with laminectomy and posterolateral fusion, the gold standard technique for nerve compression, which does have multiple complications and for this reason, alternative techniques have begun to be used. ${ }^{7}$

Different types of interspinous spacers have been studied. In 2003 , Swanson et al. ${ }^{8}$ conducted a study on cadavers in which they measured discal pressure after placement of a spacer, measured the mobility arcs in flexion, extension, and neutral positions, and reported results of a reduction of pressure in the posterior annulus and in the nucleus pulposus of $63 \%$ and $41 \%$, respectively, during extension, $38 \%$ and $20 \%$ during flexion, and with no significant changes in disc pressure in the neutral position. ${ }^{9}$

Another benefit of using interspinous spacers is that they offer distraction between the spinous process apophyses widening the foraminal canal and the spinal canal, while not affecting the adjacent levels. ${ }^{10,11}$

Several articles have been published reporting advances in the treatment of this disease. Where once rigid fixation was the goal, the new technology has taught us that it is necessary to preserve mobility as much as possible, treating only the affected level and to consider that with rigid fixation we have a phenomenon known as adjacent segment disease. Many clinical studies need to be conducted before the clinical benefits of these devices can be amply described. ${ }^{12}$ In recent years, the idea of performing minimally invasive procedures has begun to gain some ground, particularly for degenerative spine disease. While the traditional approach is still followed by most surgeons, there is growing evidence of the greater safety of these innovative procedures in properly selected patients. ${ }^{13}$

The traditional posterior midline approach has been associated with significant complications, such as muscle necrosis, muscular denervation, reduced muscular pressure, ischemia, damage to revascularization, and ligament damage. ${ }^{14,15}$ In an effort to minimize the kinds of complications associated with the open technique, minimally invasive procedures assisted by technology have begun to be used for all regions of the spine and for procedures of decompression, arthrodesis, instrumentation, and the placement of interspinous spacers. ${ }^{16}$ Many types of interspinous spacers have been developed, all of them working to limit spinal extension, and they have been of great value to patients for whom conservative treatments failed to improve the symptoms, such as in adult patients with various comorbidities. The most recently developed devices can be placed without removing bone tissue, without excessive damage at the soft tissue level, and without general anesthesia. ${ }^{17}$ Complications encountered following placement of these interspinous spacers include fractures of the spinous process apophysis, migration of the implant as a result of poor placement, ${ }^{18,19}$ and in some cases, heterotopic ossification. ${ }^{20}$

\section{CONCLUSION}

In accordance with the bibliography cited, the use of interspinous spacers for various diseases has been increasing and, although there is a lack of clinical studies, the outcomes have been positive. Minimally invasive procedures are beginning to be performed to reduce the complications that result from open techniques.

Analyzing the results obtained in this quasi-experimental study, according to the quantitative variables and the statistical methods used, the two techniques show improvements in the pain symptoms of the patients, with a greater statistical difference for the percutaneous technique. In conclusion, there will be a difference in patient progress and in functionality in daily life depending on the surgical technique performed.

All the authors declare that there are no potential conflicts of interest regarding this article.

AUTHORS' CONTRIBUTION: Each author made significant individual contributions to the preparation of the manuscript. JACR developed the concept, the study design, and analyzed and interpreted the data. JACRA developed the design and performed the critical revision. 


\section{REFERENCES}

1. Covarrubias-Gómez A. Lumbalgia: un problema de salud pública. Rev Mex Anest. 2010;33(1):106-9

2. Miralles RC, Rull M.,Valoración de los resultados del tratamiento del dolor lumbar y de las secuelas. Rev Soc Esp Dolor. 2001:8(2):131-9.

3. Castro-Menéndez M, López-Otero C, Huici-lzco R, Montero-Viéites A, Pagazaurtundua-Gómez S. Tratamiento de la estenosis del receso lateral con implante interespinoso X-STOP®. Acta Ortop. Gallega 2009;5(1):07-11.

4. Beyer F, Yagdiran A, Neu P, Kaulhausen T, Eysel P, Sobottke R. Percutaneous interspinous spacer versus open decompression: a 2-year follow-up of clinical outcome and quality of life. Eur Spine J. 2013;22(9):2015-21.

5. Tian NF, Wu AM, Wu LJ, Wu XL, WuYS, Zhang XL, et al. Incidence of heterotopic ossification after implantation of interspinous process devices. Neurosurg Focus. 2013;35(2):E3.

6. Gazzeri R, Galarza M, Alfieri A. Controversies about interspinous process devices in the treatment of degenerative lumbar spine diseases: past, present, and future. Biomed Res Int. 2014:2014:975052.

7. Parchi PD, Evangelisti G, Vertuccio A, Piolanti N, Andreani L, Cervi V, et al. Biomechanics of interspinous devices. Biomed Res Int. 2014;2014:839325.

8. Swanson KE, Lindsey DP, Hsu KY, Zucherman JF, Yerby SA. The effects of an interspinous implant on intervertebral disc pressures. Spine (Phila Pa 1976). 2003;28(1):26-32

9. Lindsey DP, Swanson KE, Fuchs P, Hsu KY, Zucherman JF Yerby SA. The effects of an interspinous implant on the kinematics of the instrumented and adjacent levels in the lumbar spine. Spine (Phila Pa 1976). 2003;28(19):2192-7.

10. Bono CM, Vaccaro AR. Interspinous process devices in the lumbar spine. J Spinal Disord Tech. 2007;20(3):255-61.
11. Kettler A, Drumm J, Heuer F, Haeussler K, Mack C, Claes $L$, et al. Can a modified interspinous spacer prevent instability in axial rotation and lateral bending? A biomechanica in vitro study resulting in a new idea. Clin Biomech (Bristol, Avon). 2008.23(2):242-7.

12. Palepu V Kodigudla M Goel VK. Biomechanics of disc degeneration. Adv Orthop. 2012;2012:726210

13. Tian NF, Zhang XL, Wu YS, Jiang LB, Xu HZ, Chi YL. Fusion after interspinous device placement. Orthopedics. 2012;35(12):e1822-5.

14. Kawaguchi $Y$, Matsui $\mathrm{H}$, Tsuji $\mathrm{H}$. Back muscle injury after posterior lumbar spine surgery. Part 1: Histologic and histochemical analyses in rats. Spine (Phila Pa 1976). 1994:19(22):2590-7.

15. Kawaguchi Y, Yabuki S, Styf J, Olmarker K, Rydevik B, Matsui H, Tsuji H. Back muscle injury after posterior lumbar spine surgery. Topographic evaluation of intramuscular pressure and blood flow in the porcine back muscle during surgery. Spine (Phila Pa 1976). 1996;21(22):2683-8.

16. Kaulhausen T, Zarghooni K, Stein G, Knifka J, Eysel P, Koebke J, et al. The interspinous spacer a clinicoanatomical investigation using plastination. Minim Invasive Surg. 2012;2012:538697.

17. Serhan $\mathrm{H}$, Mhatre $\mathrm{D}$, Defossez $\mathrm{H}$, Bono $\mathrm{CM}$. Motion-preserving technologies for degenerative lumbar spine: The past, present, and future horizons. SAS J. 2011;5(3):75-89.

18. Kim KA, McDonald M, Pik JH, Khoueir P, Wang MY. Dynamic intraspinous spacer technology for posterior stabilization: case-control study on the safety, sagittal angulation, and pain outcome at 1-year follow-up evaluation. Neurosurg Focus. 2007:22(1):E7.

19. Richter A, Halm HF Hauck M, Quante M. Two-year follow-up after decompressive surgery with and without implantation of an interspinous device for lumbar spinal stenosis: a prospective controlled study. J Spinal Disord Tech. 2014;27(6):336-41.

20. Xu C, NiWF, Tian NF, Hu XQ, Li F, Xu HZ. Complications in degenerative lumbar disease treated with a dynamic interspinous spacer (Coflex). Int Orthop. 2013:37(11):2199-204. 